\title{
UTILIZATION OF AREN (Arenga pinnata Merr.) SAWMILLING WASTE FOR EDIBLE MUSHROOM CULTIVATION MEDIA
}

\author{
Djarwanto* and Sihati Suprapti \\ Forest Product Research and Development Center \\ Jl. Gunung Batu No.5, Bogor, West Java, Indonesia
}

Received: 23 October 2013, Revised: 18 January 2016, Accepted: 26 January 2016

UTILIZATION OF AREN (Arenga pinnata Merr.) SAWMILLING WASTE FOR EDIBLE MUSHROOM CULTIVATION MEDIA. Aren (Arenga pinnata Merr.) is a multipurpose tree that can be utilized for palm sugar, alcoholic drinks, beverages and construction wood. The use of aren sawdust has not been studied intensively. This study examines the utilization of aren sawdust as cultivation media for edible mushrooms. Aren sawdust was mixed with rice bran, $\mathrm{CaCO}_{3}$, gypsum, fertilizers and distilled water before sterilization in 30 minutes pressurized autoclave at $121^{\circ} \mathrm{C}$ and $1.5 \mathrm{~atm}$. The mixed media was inoculated with pure cultures containing four mushrooms species (Pleurotus flabellatus, P. ostreatus, P. sajor-caju and Lentinula edodes) and incubated for five weeks to allow mycelium growth producing fruit bodies. The fruit bodies were harvested everyday within four months and examined for its gained mushroom-weight and biological conversion efficiency/BE. The core part of aren trunk was cut into smaller pieces of $10 \mathrm{~cm}$ (width) by $5 \mathrm{~cm}$ (thickness), by $120 \mathrm{~cm}$ (length). Each core sample was bored from the surface inward, creating holes with a particular distance apart. Each hole was inoculated with pure cultures containing 6 mushroom species (four species above, P. cystidiosus and Auricularia polytricha). The inoculated samples were slanted on bamboo support, and placed in a bamboo hut. Harvesting was carried out everyday after the fruiting body became mature and examined for its gained mushroom weight. Results show that the use of sawdust supplemented with nutritious material is more likely to improve the mushroom yield than that of aren sawn-timber core. In this case, the BE values with aren-sawdust media were $21.97-89.45 \%$ (P. flabellatus), 15.36-105.36\% (P. ostreatus), 63.88-76.86\% (P. sajor-caju), and up to $62.88 \%$ (L. edodes). Meanwhile, the yields (gained mushroom weight) with aren sawn-timber media were $210 \mathrm{~g}$ (P. ostreatus), 368g (P. flabellatus), 331g (P. sajor-caju) and 48g (A. polytricha); however, P. cystidiosus and L. edodes inoculated on aren stem core failed to grow..

Keywords: Aren core, biological conversion efficiency, medium, mushroom, sawdust

PEMANFAATAN LIMBAH PENGGERGAJLAN KAYU AREN (Arenga pinnata Merr.) UNTUK MEDIA BUDIDAYA JAMUR KAYU YANG DAPAT DIMAKAN. Aren (Arenga pinnata Merr.) termasuk ke dalam kelompok pohon serbaguna: niranya dibuat gula dan minuman beralkohol, buabnya untuk cocktail, kayunya untuk. kostruksi bangunan. Studi pemanfaatan serbuk gergajian kayu aren belum dilakukan secara intensif. Penelitian ini bertujuan untuk. mengkaji pemanfaatan serbuk gergajian kayu aren untuk media budidaya jamur kayu yang dapat dimakan. Serbuk gergajian kayu aren dicampur dengan dedak, $\mathrm{CaCO}_{3}$, gypsum, pupuk dan air suling dengan komposisi tertentu kemudian disterilkan dengan autoklaf selama 30 menit pada subu $121^{\circ} \mathrm{C}$ dan tekanan 1,5 atmosfer. Setelah dingin, kantong-kantong media dibagi 4 kelompok, masing-masing diinokulasi dengan biakan murni empat jenis jamur, yaitu: Pleurotus flabellatus, P. ostreatus, P. sajor-caju, dan Lentinula edodes kemudian diinkubasikan selama kurang lebih lima minggu untuk memberi kesempatan tumbubnya miselium membentuk tubub buah jamur. Jamur dipanen setiap bari selama tubuh buahnya tumbuh sampai sekitar 4 bulan. Data basil panen per kantong media diakumulasikan kemudian dibitung nilai efisiensi konversi biologinya (EB). Selain itu, limbah berupa hati batang aren dibuat contoh uji dengan ukuran lebar 10 $\mathrm{cm}$, tebal $5 \mathrm{~cm}$ dan panjang $120 \mathrm{~cm}$. Contoh uji dilubangi dengan bor pada jarak, tertentu, kemudian ke dalam setiap lubang diinokulasi biakan murni 6 jenis jamur yaitu 4 jenis sama seperti pada media serbuk gergajian ditambah dua jenis yaitu $\mathrm{P}$. cystidiosus, dan Auricularia polytricha. Contoh uji yang sudah diinokulasi jamur disandarkan sedemikian rupa di dalam

${ }^{*}$ Corresponding author: djarwanto@yahoo.co.id 
gubug bambu. Panen jamur dilakukan setiap hari setelah tubub buah masak. petik. Seperti halnya pada serbuk gergajian, basil panen jamur ditimbang. Hasilnya menunjukkan babwa penggunaan media dari serbuk gergajian kayu aren yang mengandung suplemen lebib baik dibandingkan dengan media hati batang aren. Nilai EB pada media dari serbuk gergajian kayu aren yaitu 21,97-89,45\% (Pleurotus flabellatus), 15,36-105,36\% (P. ostreatus), 63,88-76,86\% (P. sajor-caju), dan 62,88\% (L. edodes). Sedangkan rata-rata hasil panen jamur pada media hati batang aren yaitu $210 \mathrm{~g}$ (P. ostreatus), $368 g$ (P. flabellatus), $331 g$ (P. sajor-caju), dan $48 g$ (A. polytricha); sedangkan P. cystidiosus dan L. edodes tidak dapat tumbuh pada hati batang aren.

Kata kunci: Efisiensi konversi biologi, hati batang aren, jamur, media, serbuk gergaji kayu

\section{INTRODUCTION}

Aren (Arenga pinnata Merr.) is a multipurpose tree which all parts of this plant can be utilized for various products. The stem can be used for construction, injuk (base of leaves petiole in the form of black hairy fibers or the so-called thatch), young leaves, sago starch extracted rom the pith, nira (sweet juicy liquid tapped from the flower) and kolang-kaling (young fleshy fruit). Its root can be utilized for webbing materials and whipping stuffs; palm pith can be eaten as vegetable; the rib of leaf can be used as brooms and baskets; the young leaves are as substitute for cigarette paper or used as thatching or roofing for housing; and injuk fibers (taken from the base of petioles) are used in the manufacture of brushes, brooms and ropes. The flower produce sap or aren juice, often called as nira that can be used for alcoholic drink, vinegar and sugar. The young aren fruit, which is called kolang-kaling, usually used for cocktail (Lempang, 2012).

In term of sap production, the plant productive age is Aren trees begin in flower at 12-16 years of age and the tapping of the sap (nira) can be carried out for another 3-5 years. Afterwards, the sap tapping is no longer economical, and the unproductive trees will die gradually, thereby leaving behind some particular parts as wastes such as stems, leaves and injuk fibers. As the trees get older, they someday become unproductive for such, leaving behind also among others their trunks abundantly which can be utilized for timber or other building component. Unfortunately, such usages generate also enormous wastes, i.e. aren sawdust and sawn-timber cores.
Therefore, those wastes are necessary to be used optimally. The hollowed stem is usually used for water-conducting pipe, and its core can be extracted for sago (Heyne, 1987). The outer layer or periphery of aren stem is very hard, and it can be used for housing component, floorings, stairs, poles and agricultural tool handles. Recovery of such products (items) from the sawmilling of aren stem (trunk) is around 13.48\% (Rachman, Rohadi, \& Balfas, 1989). The rest resulting from that activity revealed that as much approximately $86.52 \%$ of aren stems is generated as sawdust and aren core. The possibility of utilization of those wastes for mushroom cultivation can hopefully accelerate their destroying (degrading) process into the compost. Concurrently, this process produces fruit bodies of edible mushroom. Chemical analysis showed that the periphery part of aren stem consists of cellulose $21.69 \%$, lignin $33.76 \%$, pentosan $19.60 \%$, ash $1.40 \%$ and silica $0.52 \%$. Meanwhile, the central part (aren core) contains cellulose $44.83 \%$, lignin $36.78 \%$, pentosan $16.58 \%$, ash $4.34 \%$ and silica $1.32 \%$ (Gusmailina \& Hartoyo, 1989). In relevant, this paper scrutinizes the trial results regarding the possible utilization of wastes from aren sawmilling (i.e. aren sawdust and aren core) as the cultivation medium for edible mushrooms.

\section{MATERIAL AND METHOD}

\section{A. Materials}

The main materials used as the cultivation media for edible mushrooms comprised of aren sawdust and aren core. They were collected and taken from the sawmilling laboratory of Forest 
Products Research and Development Center as a waste. Mushrooms spawn comprised of pure culture in agar medium and spawn cultured in wood sawdust of sengon (Falcataria moluccana (L.) Nielsen).

The activities of this research consisted of two experiments as follows:

\section{B. Methods}

\section{Trial I: Cultivation on sawdust}

Mushrooms cultivation was done under natural room condition (with temperature $22-31^{\circ} \mathrm{C}$, and $\mathrm{rH} 74-95 \%$ ) in the laboratory of Mycology Forest Products Research and Development Center. Aren sawdust samples as used for the cultivation media of edible mushroom were each added (mixed) with other supplement stuffs, comprising rice bran, gypsum $\left(\mathrm{CaSO}_{4} 2 \mathrm{H}_{2} \mathrm{O}\right)$, fertilizers [ammonium sulphate $\left./ \mathrm{ZA}\left(\left(\mathrm{NH}_{4}\right) 2 \mathrm{SO}_{4}\right)\right)$, urea $\left(\mathrm{CH}_{4} \mathrm{~N}_{2} \mathrm{O}\right)$, NPK/Nitrogen phosphorus $\left(\mathrm{P}_{2} \mathrm{O}_{5}\right)$ and potassium $\left(\mathrm{K}_{2} \mathrm{O}\right)$, trisuperphosphate/TSP $\left.\mathrm{Ca}\left(\mathrm{H}_{2} \mathrm{PO}_{4}\right) 2 \mathrm{H}_{2} \mathrm{O}\right)$, and potassium chloride/ $\mathrm{KCl}$, and distilled water, with the particular compositions (A, B, C and D) as follows:

A: sawdust $95-75 \%+$ rice bran 5-25\% + sufficient amount of distilled water.

B: sawdust $84.5-82.5 \%+$ rice bran $15 \%$ $+\mathrm{CaCO}_{3} 0.5-2.5 \%+$ sufficient amount of distilled water

C: sawdust $84.5-82.5 \%+$ rice bran $15 \%$ + gypsum $0.5-2.5 \%+$ sufficient amount of distilled water

D: sawdust $77.5 \%+$ rice bran $20 \%+\mathrm{CaCO}_{3}$ $2 \%+$ fertilizers $0.5 \%+$ sufficient distilled water

The amount of distilled water as added was 100 to $120 \%$ per dry weight of stuffs (materials). The already prepared media were placed into a PVC (polyvinyl chloride) plastic bag with the total weight of 500 grams for each, prior to their sterilization in an autoclave. The sterilized media with the composition $\mathrm{A}$ and $\mathrm{D}$ were then each inoculated by pure cultures each comprising consecutively white oyster mushroom (Pleurotus ostreatus), pink oyster mushroom (P. flabellatus), grey oyster mushroom (P. sajor-caju) and shiitake (Lentinula edodes; originated from Japan). Meanwhile, composition $\mathrm{B}$ and $\mathrm{C}$ were each inoculated by P. ostreatus and P. flabellatus. All the inoculated media were then incubated until the mycelium growth (white fibrous formation) from the mushroom partially became well distributed. Each of the treatments (A, B, C, D) was made of five subsamples, further regarded as replicates. Harvesting of mushrooms was carried out every day (and weighed) after the fruiting body of the cultivated mushroom was mature, which lasted for four months' observations.

\section{Trial II: Cultivation on aren core}

The cultivation media were each prepared from the samples aren core's sawn timber which dimension of $10 \mathrm{~cm}$ (width) by $5 \mathrm{~cm}$ (thick) by $120 \mathrm{~cm}$ (length). Each of the core samples was bored on its surface by a hand driller thereby creating holes inward, each with $1.27 \mathrm{~cm}$ in diameter and $2 \mathrm{~cm}$ in depth. Each of the holes was prepared by a 15 to $20 \mathrm{~cm}$ in distance apart. Inoculations by mushrooms spawn cultured in wood sawdust were carried out into each hole until the hole was full of spawn and gently compacted. Six mushroom species were tested, i.e. by Pleurotus ostreatus, $P$. flabellatus, P. sajor-caju, P. cystidiosus, Auricularia polytricha (ears mushrooms) and Lentinula edodes (origin from Japan and Kalimantan), whereby each species was inoculated on ten samples as replications. The inoculated samples were then slanted on bamboo support with an angle of \pm $60^{\circ}$, placed in a $1.5 \mathrm{~m}$ by $2.0 \mathrm{~m}$ bamboo hut and located at Bogor. In order to keep moist the environment, the samples were watered twice every day. The further staged procedures on the samples as the media for mushroom cultivation were similar to those as implemented on the aren-sawdust samples. Harvesting was carried out every day after the fruiting body became mature, remarked by the edges becoming thin out. Likewise, the harvesting yields were examined for the gained mushroom weight and BE values (Djarwanto \& Suprapti, 2010). 


\section{Data Analysis}

The cumulative weighing data (freshly harvested mushrooms) in gram from each of compositions (treatments) were analyzed by a completely randomized design (CRD). The biological conversion efficiency (BE) was calculated as total gained weight of the freshly harvested mushroom divided by the weight of the dried cultivation media, further presented in percentage (Djarwanto \& Suprapti, 2010). Likewise, the BE data were also analyzed by a CRD (Steel \& Torrie, 1981).

\section{RESULT AND DISCUSSION}

The data of mushrooms weight and biological conversion efficiency (BE) value on aren sawmilling wastes are presented on Table 1-5.

\section{A. Cultivation of Mushrooms on Aren Sawdust}

The growth of mycelium of mushroom on the surface of each cultivation media sample had dispersed evenly one month after mushroom inoculation. Mushrooms of Pleurotus ostreatus, $P$. flabellatus and P. sajor-caju were already mature for the harvesting of their fruit body on the third day after the primordial growth; however, for Lentinula edodes species it took 5-14 days to reach such maturity. Narh et al. (2011), Djarwanto and Suprapti (2001), Suprapti and Djarwanto (2001, 2009) stated that Pleurotus ostreatus, P. flabellatus and P. sajor-caju were already mature for harvesting on $3^{\text {rd }}-4^{\text {th }}$ day after the primordial as steadily grown shaped like a pinhead. The first harvesting occurrences for fruiting body of those mushrooms were 30-179 days

Table 1. The averages of mushroom weight of Pleurotus flabellatus and biological conversion efficiency (BE) value on aren sawdust media

\begin{tabular}{|c|c|c|c|c|c|c|}
\hline $\begin{array}{l}\text { Treat- } \\
\text { ment }\end{array}$ & $\begin{array}{c}\text { Composition of medium } \\
{[\text { part } \%]}\end{array}$ & $\begin{array}{c}\text { First } \\
\text { harvesting } \\
\text { occasion } \\
\text { [days] }\end{array}$ & Weight [g] & $\begin{array}{l}\text { Number } \\
\text { of pileus }\end{array}$ & $\begin{array}{c}\text { Harvesting } \\
\text { frequency } \\
\text { [times] }\end{array}$ & $\mathrm{BE}[\%]$ \\
\hline \multirow[t]{5}{*}{ A } & S $95+$ R 5 & 69 & $134.83 \mathrm{~d}$ & 86.8 & 4.8 & $61.93 \mathrm{c}$ \\
\hline & $\mathrm{S} 90+\mathrm{R} 10$ & 48 & $117.67 \mathrm{e}$ & 68.0 & 4.5 & $51.38 \mathrm{~d}$ \\
\hline & $\mathrm{S} 85+\mathrm{R} 15$ & 48 & $150.33 \mathrm{bc}$ & 94.0 & 5.5 & $66.24 \mathrm{~b}$ \\
\hline & $\mathrm{S} 80+\mathrm{R} 20$ & 48 & $192.50 \mathrm{a}$ & 108.2 & 7.3 & $83.84 \mathrm{a}$ \\
\hline & $\mathrm{S} 75+\mathrm{R} 25$ & 48 & $140.83 \mathrm{~cd}$ & 87.0 & 4.8 & $60.84 \mathrm{c}$ \\
\hline \multirow[t]{5}{*}{$\mathrm{B}$} & $\mathrm{S} 84.5+\mathrm{R} 15+\mathrm{Ca} 0.5$ & 43 & $132.17 \mathrm{c}$ & 78.5 & 4.8 & $53.13 \mathrm{c}$ \\
\hline & $\mathrm{S} 84+\mathrm{R} 15$ + Ca 1 & 43 & $170.17 \mathrm{a}$ & 101.7 & 4.5 & $68.64 \mathrm{a}$ \\
\hline & $\mathrm{S} 83.5+\mathrm{R} 15+\mathrm{Ca} 1.5$ & 43 & $145.50 \mathrm{~b}$ & 95.5 & 5.0 & $58.49 \mathrm{a}$ \\
\hline & $\mathrm{S} 83+\mathrm{R} 15+\mathrm{Ca} 2$ & 43 & $156.00 \mathrm{ab}$ & 84.0 & 4.5 & $63.13 \mathrm{ab}$ \\
\hline & $\mathrm{S} 82.5+\mathrm{R} 15+\mathrm{Ca} 2.5$ & 43 & $149.67 \mathrm{~b}$ & 104.7 & 5.3 & $59.97 \mathrm{bc}$ \\
\hline \multirow[t]{5}{*}{$\mathrm{C}$} & $\mathrm{S} 84.5+\mathrm{R} 15+\mathrm{G} 0.5$ & 60 & $70.33 \mathrm{~b}$ & 49.2 & 3.8 & $26.60 \mathrm{~b}$ \\
\hline & $\mathrm{S} 84+\mathrm{R} 15+\mathrm{G} 1$ & 64 & $66.50 \mathrm{bc}$ & 43.0 & 4.2 & $27.36 \mathrm{~b}$ \\
\hline & $\mathrm{S} 83.5+\mathrm{R} 15+\mathrm{G} 1.5$ & 65 & 54.83 c & 31.3 & 3.3 & $21.96 \mathrm{~b}$ \\
\hline & $\mathrm{S} 83+\mathrm{R} 15+\mathrm{G} 2$ & 65 & $65.50 \mathrm{bc}$ & 44.7 & 4.0 & $26.76 \mathrm{~b}$ \\
\hline & $\mathrm{S} 82.5+\mathrm{R} 15+\mathrm{G} 2.5$ & 47 & $106.00 \mathrm{a}$ & 71.7 & 4.5 & $41.34 \mathrm{a}$ \\
\hline \multirow[t]{5}{*}{$\mathrm{D}$} & $\mathrm{S} 77.5+\mathrm{R} 20+\mathrm{Ca} 2+\mathrm{ZA} 0.5$ & 36 & $203.00 \mathrm{a}$ & 160.8 & 7.3 & $89.45 \mathrm{a}$ \\
\hline & $\mathrm{S} 77.5+\mathrm{R} 20+\mathrm{Ca} 2+\mathrm{TSP} 0.5$ & 36 & $140.53 \mathrm{~b}$ & 124.7 & 5.3 & $61.84 \mathrm{~b}$ \\
\hline & $\mathrm{S} 77.5+\mathrm{R} 20+\mathrm{Ca} 2+\mathrm{NPK} 0.5$ & 42 & $195.67 \mathrm{a}$ & 139.8 & 6.3 & $84.66 \mathrm{a}$ \\
\hline & $\mathrm{S} 77.5+\mathrm{R} 20+\mathrm{Ca} 2+\mathrm{KCl} 0.5$ & 43 & $150.67 \mathrm{~b}$ & 115.0 & 5.5 & $64.99 \mathrm{~b}$ \\
\hline & $\mathrm{S} 77.5+\mathrm{R} 20+\mathrm{Ca} 2+$ urea 0.5 & 30 & $200.50 \mathrm{a}$ & 116.2 & 6.3 & $87.15 \mathrm{a}$ \\
\hline
\end{tabular}

Remarks: ${ }^{\mathrm{S}}$ Sawdust, Rrice bran, ${ }^{\mathrm{Ca}} \mathrm{CaCO},{ }_{3}{ }^{\mathrm{G}}$ gypsum, ${ }^{\mathrm{KCl}}$ Potassium Chloride, ${ }^{\mathrm{ZA}}$ ammonium sulphate, ${ }^{\mathrm{TSP}}$ trisuperphosphate, $\mathrm{N}^{\mathrm{PK}}$ nitrogen phosphorus potassium. Numbers within each a column followed by the same letter, mean non significantly different, Tukey test $(\mathrm{P} \leq 0.05)$ 
Table 2. The averages of mushroom weight of Pleurotus ostreatus and biological conversion efficiency (BE) value on aren sawdust media

\begin{tabular}{|c|c|c|c|c|c|c|}
\hline $\begin{array}{l}\text { Treat- } \\
\text { ment }\end{array}$ & Composition of media $[\%]$ & $\begin{array}{l}\text { First harvesting } \\
\text { occasion [days] }\end{array}$ & $\begin{array}{c}\text { Weight } \\
\text { [g] }\end{array}$ & $\begin{array}{l}\text { Number } \\
\text { of pileus }\end{array}$ & $\begin{array}{c}\text { Harvesting } \\
\text { frequency } \\
\text { [times] }\end{array}$ & $\mathrm{BE}[\%]$ \\
\hline \multirow[t]{5}{*}{ A } & S $95+$ R 5 & 69 & $35.5 \mathrm{c}$ & 6.2 & 1.6 & $15.36 \mathrm{c}$ \\
\hline & S $90+$ R 10 & 54 & $39.5 \mathrm{c}$ & 12.0 & 1.5 & $16.96 \mathrm{c}$ \\
\hline & $\mathrm{S} 85+\mathrm{R} 15$ & 53 & $69.5 \mathrm{~b}$ & 19.3 & 1.8 & $29.98 \mathrm{~b}$ \\
\hline & $\mathrm{S} 80+\mathrm{R} 20$ & 50 & $63.5 \mathrm{~b}$ & 22.2 & 1.8 & $27.01 \mathrm{~b}$ \\
\hline & $\mathrm{S} 75+\mathrm{R} 25$ & 52 & $112.67 \mathrm{a}$ & 33.2 & 3.3 & $51.30 \mathrm{a}$ \\
\hline \multirow[t]{5}{*}{ B } & $\mathrm{S} 84.5+\mathrm{R} 15+\mathrm{Ca} 0.5$ & 44 & $151.33 \mathrm{~b}$ & 41.3 & 3.0 & $59.83 \mathrm{~b}$ \\
\hline & $\mathrm{S} 84+\mathrm{R} 15+\mathrm{Ca} 1$ & 44 & $157.67 \mathrm{~b}$ & 55.7 & 3.2 & $62.33 \mathrm{~b}$ \\
\hline & $\mathrm{S} 83.5+\mathrm{R} 15+\mathrm{Ca} 1.5$ & 46 & $191.00 \mathrm{a}$ & 66.3 & 3.8 & $75.63 \mathrm{a}$ \\
\hline & $\mathrm{S} 83+\mathrm{R} 15+\mathrm{Ca} 2$ & 44 & $149.33 \mathrm{~b}$ & 54.0 & 2.8 & $59.53 \mathrm{~b}$ \\
\hline & $\mathrm{S} 82.5+\mathrm{R} 15+\mathrm{Ca} 2.5$ & 44 & $153.67 \mathrm{~b}$ & 46.2 & 3.0 & $61.06 \mathrm{~b}$ \\
\hline \multirow[t]{5}{*}{$\mathrm{C}$} & $\mathrm{S} 84.5+\mathrm{R} 15+\mathrm{G} 0.5$ & 44 & $184.67 \mathrm{a}$ & 56.7 & 5.3 & $79.28 \mathrm{a}$ \\
\hline & $\mathrm{S} 84+\mathrm{R} 15+\mathrm{G} 1$ & 42 & $200.67 \mathrm{a}$ & 48.8 & 5.8 & $85.62 \mathrm{a}$ \\
\hline & $\mathrm{S} 83.5+\mathrm{R} 15+\mathrm{G} 1.5$ & 41 & $196.33 \mathrm{a}$ & 61.3 & 5.7 & $84.16 \mathrm{a}$ \\
\hline & $\mathrm{S} 83+\mathrm{R} 15+\mathrm{G} 2$ & 42 & $199.13 \mathrm{a}$ & 60.5 & 5.8 & $84.43 \mathrm{a}$ \\
\hline & $\mathrm{S} 82.5+\mathrm{R} 15+\mathrm{G} 2.5$ & 44 & 200,67 a & 64.7 & 5.2 & $87.23 \mathrm{a}$ \\
\hline \multirow[t]{5}{*}{$\mathrm{D}$} & $\mathrm{S} 77.5 \%+\mathrm{R} 20+\mathrm{Ca} 2+\mathrm{ZA} 0.5$ & 37 & $210.67 \mathrm{ab}$ & 58.7 & 5.7 & $91.43 \mathrm{ab}$ \\
\hline & S $77.5+$ R $20+$ Ca $2+$ TSP 0.5 & 37 & $163.17 \mathrm{~b}$ & 53.7 & 5.6 & $78.04 \mathrm{~b}$ \\
\hline & $\mathrm{S} 77.5+\mathrm{R} 20+\mathrm{Ca} 2+\mathrm{NPK} 0.5$ & 37 & $239.83 \mathrm{a}$ & 80.5 & 6.7 & $105.05 \mathrm{a}$ \\
\hline & $\mathrm{S} 77.5+\mathrm{R} 20+\mathrm{Ca} 2+\mathrm{KCl} 0.5$ & 37 & $194.00 \mathrm{ab}$ & 41.0 & 5.0 & $83.55 \mathrm{ab}$ \\
\hline & $\mathrm{S} 77.5+\mathrm{R} 20+\mathrm{Ca} 2+$ urea 0.5 & 37 & $237.00 \mathrm{a}$ & 102.2 & 5.7 & $102.38 \mathrm{ab}$ \\
\hline
\end{tabular}

Remarks: ${ }^{\mathrm{S}}$ Sawdust, ${ }^{\mathrm{R}}$ rice bran, ${ }^{\mathrm{Ca}} \mathrm{CaCO}_{3}$, ${ }^{\mathrm{G}}$ gypsum. Numbers within each a column followed by the same letter, mean non significantly different, Tukey test $(\mathrm{P}<0.05)$

after their inoculation (Tables 1, 2, 3, and 4). Djarwanto and Suprapti (2001), and Djarwanto, Yamto and Roliadi (2004) reported that the initial harvest occasions of oyster mushrooms were around 26-51 days (for P. ostreatus), 26-30 days P. flabellatus, 36-61 days (P. sajor-caju) and 139-150 days (L. edodes) after their inoculation. Shah, Ashraf and Ishtiaq (2004) stated that the fruiting body of $\mathrm{P}$. ostreatus could be harvested about 27-34 days after inoculation. Djarwanto and Suprapti (2001) reported that the first harvesting of $L$. edodes was about 93194 days after inoculation. The mushroom yield, harvesting frequency, and $\mathrm{BE}$ value are presented at Table 1 (for P. flabellatus), Table 2 (P. ostreatus), Table 3 (P. sajor-caju), and Table 4 (L. edodes). According to statistical analysis, supplementation of rice bran, minerals and fertilizers was generally significantly influencing the mushroom weight and $\mathrm{BE}$ value $(\mathrm{p} \leq 0.05)$.
Concerning the rice bran supplementation (incorporation) on media, the highest yield (with respect to the weight and $\mathrm{BE}$ values) could be reached with rice bran percentages as much as consecutively 20\% (P. flabellatus), 25\% (P. ostreatus), 10\% (P. sajor-caju), 10\% and 20\% (L. edodes), as shown on Tables 1, 2, 3, 4. Suprapti (1988) reported that rice bran supplementation as much as $10-20 \%$ did not significantly affect the yield. The lowest yield was found on the media with $5 \%$ rice bran. The average yields on the media with rice bran supplementation were 147.23 grams (P. flabellatus), 64.13 grams (P. ostreatus), 140.50 grams (P. sajor-caju), and 65.80 grams (L. edodes). Such low yield values were caused by the developing failure and wilting of the primordial. The averages of the $\mathrm{BE}$ values were $68.41 \%$ (P. flabellatus), $28.81 \%$ (P. ostreatus), 65.85\% (P. sajor-caju), and 36.41\% (L. edodes) (Table 1, 2, 3, 4). The BE value of 
Table 3. The averages of mushroom weight of Pleurotus sajor-caju and biological conversion efficiency (BE) value on aren sawdust media

\begin{tabular}{|c|c|c|c|c|c|c|}
\hline $\begin{array}{l}\text { Treat- } \\
\text { ment }\end{array}$ & Composition of media $[\%]$ & $\begin{array}{l}\text { First harvesting } \\
\text { occasion [days] }\end{array}$ & $\begin{array}{c}\text { Weight } \\
{[\mathrm{g}]}\end{array}$ & $\begin{array}{l}\text { Number } \\
\text { of pileus }\end{array}$ & $\begin{array}{c}\text { Harvesting } \\
\text { frequency } \\
\text { [times] }\end{array}$ & $\mathrm{BE}[\%]$ \\
\hline \multirow{4}{*}{ A } & S $95+$ R 5 & 64 & $112.6 \mathrm{~b}$ & 22.2 & 5.0 & $66.74 \mathrm{a}$ \\
\hline & $\mathrm{S} 90+\mathrm{R} 10$ & 64 & $146.4 \mathrm{a}$ & 27.4 & 5.2 & $68.60 \mathrm{a}$ \\
\hline & $\mathrm{S} 85+\mathrm{R} 15$ & 103 & $137.0 \mathrm{a}$ & 22.6 & 5.4 & $64.11 \mathrm{a}$ \\
\hline & $\mathrm{S} 80+\mathrm{R} 20$ & 110 & $136.2 \mathrm{a}$ & 25.6 & 4.8 & $63.88 \mathrm{a}$ \\
\hline \multirow{5}{*}{$\mathrm{D}$} & $\mathrm{S} 77.5+\mathrm{R} 20+\mathrm{Ca} 2+\mathrm{ZA} 0.5$ & 107 & $145.2 \mathrm{ab}$ & 28.8 & 4.6 & $72.81 \mathrm{a}$ \\
\hline & $\mathrm{S} 77.5+\mathrm{R} 20+\mathrm{Ca} 2+\mathrm{TSP} 0.5$ & 114 & $152.6 \mathrm{ab}$ & 26.2 & 5.8 & $76.86 \mathrm{a}$ \\
\hline & $\mathrm{S} 77.5+\mathrm{R} 20+\mathrm{Ca} 2+\mathrm{NPK} 0.5$ & 69 & $145.6 \mathrm{ab}$ & 24.6 & 5.0 & $67.95 \mathrm{ab}$ \\
\hline & $\mathrm{S} 77.5+\mathrm{R} 20+\mathrm{Ca} 2+\mathrm{KCl} 0.5$ & 129 & $112.2 \mathrm{c}$ & 20.4 & 3.4 & $56.07 \mathrm{~b}$ \\
\hline & $\mathrm{S} 77.5+\mathrm{R} 20+\mathrm{Ca} 2+$ urea 0.5 & 114 & $129.2 \mathrm{bc}$ & 23.0 & 5.8 & $76.56 \mathrm{a}$ \\
\hline
\end{tabular}

Remarks: ${ }^{S}$ Sawdust, ${ }^{\mathrm{R}}$ rice bran, ${ }^{\mathrm{C} a} \mathrm{CaCO}_{3}$, ${ }^{\mathrm{G}}$ gypsum. Numbers within each a column followed by the same letter, mean non significantly different, Tukey test $(\mathrm{P} \leq 0.05)$

Table 4. The average mushroom weight of Lentinula edodes and biological conversion efficiency (BE) value on aren sawdust media

\begin{tabular}{|c|c|c|c|c|c|c|}
\hline $\begin{array}{l}\text { Treat- } \\
\text { ment }\end{array}$ & Composition of media $[\%]$ & $\begin{array}{l}\text { First harvesting } \\
\text { occasion [days] } \\
\qquad * *\end{array}$ & Weight $[\mathrm{g}]$ & $\begin{array}{l}\text { Number } \\
\text { of pileus }\end{array}$ & $\begin{array}{c}\text { Harvesting } \\
\text { frequency } \\
\text { [times] }\end{array}$ & $\mathrm{BE}[\%]$ \\
\hline \multirow[t]{5}{*}{$\mathrm{A}$} & S $95+$ R 5 & 118 & $70.0 \mathrm{~b}$ & 3.8 & 1,4 & $30.99 \mathrm{~b}$ \\
\hline & $\mathrm{S} 90+\mathrm{R} 10$ & 143 & $71.0 \mathrm{~b}$ & 3.0 & 2.0 & $31.76 \mathrm{~b}$ \\
\hline & $\mathrm{S} 85+\mathrm{R} 15$ & 74 & $146.0 \mathrm{a}$ & 6.0 & 1.0 & $62.88 \mathrm{a}$ \\
\hline & $\mathrm{S} 80+\mathrm{R} 20$ & 143 & $42.0 \mathrm{c}$ & 1.0 & 1.0 & $20,02 \mathrm{c}$ \\
\hline & S $75+$ R 25 & $0^{*}$ & $0^{*} \quad \mathrm{~d}$ & $0 *$ & $0 *$ & $0^{*} \quad \mathrm{~d}$ \\
\hline \multirow[t]{5}{*}{$\mathrm{D}$} & $\mathrm{S} 77.5+\mathrm{R} 20+\mathrm{Ca} 2+\mathrm{ZA} 0.5$ & 138 & $22.5 \mathrm{~b}$ & 1.0 & 2.0 & $11.28 \mathrm{~b}$ \\
\hline & $\mathrm{S} 77.5+\mathrm{R} 20+\mathrm{Ca} 2+\mathrm{TSP} 0.5$ & 179 & $50.0 \mathrm{a}$ & 2.0 & 1.0 & $25.19 \mathrm{a}$ \\
\hline & $\mathrm{S} 77.5+\mathrm{R} 20+\mathrm{Ca} 2+\mathrm{NPK} 0.5$ & $0^{*}$ & $0^{*} \quad \mathrm{c}$ & $0 *$ & $0 *$ & $0^{*} \quad \mathrm{c}$ \\
\hline & $\mathrm{S} 77.5+\mathrm{R} 20+\mathrm{Ca} 2+\mathrm{KCl} 0.5$ & $0^{*}$ & $0^{*} \mathrm{c}$ & $0^{*}$ & $0^{*}$ & $0^{*} \quad \mathrm{c}$ \\
\hline & $\mathrm{S} 77.5+\mathrm{R} 20+\mathrm{Ca} 2+$ urea 0.5 & $0^{*}$ & $0^{*} \quad \mathrm{c}$ & $0 *$ & $0 *$ & $0^{*} \quad \mathrm{c}$ \\
\hline
\end{tabular}

Remarks: ${ }^{\mathrm{S}}$ Sawdust, ${ }^{\mathrm{R}}$ rice bran, ${ }^{\mathrm{Ca}} \mathrm{CaCO}_{3}$, ${ }^{\mathrm{G}}$ gypsum. ${ }^{*}$ fruit body rotten and not develop. Numbers within each a column followed by the same letter, mean non significantly different, Tukey test $(\mathrm{P} \leq 0.05)$

Table 5. The average mushroom weight on media made of sawn timber of aren core

\begin{tabular}{|c|c|c|c|c|c|}
\hline No. & Mushroom species & $\begin{array}{c}\text { First harvesting } \\
\text { occasion [days] }{ }^{* * *}\end{array}$ & Weight $[\mathrm{g}]$ & $\begin{array}{l}\text { Number } \\
\text { of pileus }\end{array}$ & $\begin{array}{c}\text { Harvesting frequency } \\
\text { [times] }\end{array}$ \\
\hline 1 & P. flabellatus & 43 & 368.2 & 591.4 & 10.8 \\
\hline 2 & P. ostreatus & 64 & 210.3 & 37.0 & 4.3 \\
\hline 3 & P. sajor-caju & 136 & 331.5 & 129.2 & 5.5 \\
\hline 4 & P. cystidiosus & $0 *)$ & $0 *)$ & $0 *)$ & $0 *)$ \\
\hline 5 & A. polytricha & 99.0 & 48.0 & 67.0 & 2.0 \\
\hline 6 & L. edodes (Japan) & $0 * *)$ & $0 * *)$ & $0 * *)$ & $0 * *)$ \\
\hline 7 & L. edodes (Kalimantan) & $0 * *)$ & $0 * *)$ & $0 * *)$ & $0 * *)$ \\
\hline
\end{tabular}

${ }^{*}$ Remarks: Primordium did not develop, ${ }^{* *}$ fruit body did not grow; ${ }^{* *)}$ after mushroom-spawn inoculation

P. ostreatus was generally lower than the value of the previous research results on medium made of sawdust of Hevea brasiliensis Muell. Arg. and
Mangifera caesia Jack. (Suprapti, 1988). Because of insufficient materials, P. sajor-caju had not been cultivated on media with $25 \%$ rice bran. 
Fruit body of $L$. edodes was not found on media with $25 \%$ rice bran due to the media rotting and or drying.

$\mathrm{CaCO}_{3}$ supplementation was significantly influencing the $P$. flabellatus and $P$. ostreatus yield $(\mathrm{p}<0.05)$. It is shown that higher $\mathrm{CaCO}_{3}$ percentage did not always improves or bring about changes on the yield. The highest yields were found on media with $\mathrm{CaCO}_{3}$ percentages at $1 \%$ (P. flabellatus) and $1.5 \%$ (P. ostreatus), with $\mathrm{BE}$ values reaching $68.64 \%$ and $75.63 \%$, respectively (Tables 1, 2). FAO (1982) and Suprapti et al. (1994) stated that the optimum amount of calcium-containing compound to be added into the substrate ranged about $1-2.5 \%$. The average yields (i.e. mushroom weight) on media using $\mathrm{CaCO}_{3}$ supplementation were 150.70 grams (P. flabellatus) and 160.60 grams ( $P$. ostreatus), with BE values consecutively $60.69 \%$ and $63.68 \%$. Those values were still close to the $B E$ values with the same mushroom species but on rubberwood media (Suprapti \& Djarwanto, 1990).

Gypsum supplementation on media inoculated with $P$. ostreatus was not significantly influencing the yield $(p<0.05)$. The highest yield (mushroom weight) and $\mathrm{BE}$ value were found on media with $2.5 \%$ gypsum. The average yields from media with gypsum were consecutively 72.63 grams (P. flabellatus) and 199.20 grams ( $P$. ostreatus); whereas, the corresponding $\mathrm{BE}$ value were $28.81 \%$ and $84.14 \%$, respectively. Those values were higher than the results of previous research with the same mushroom species but on rubberwood sawdust media (Suprapti \& Djarwanto, 1990).

Fertilizers supplementation was generally able to increase the mushroom yield (i.e. weight and $\mathrm{BE}$ values), whereby different kinds of fertilizers were significantly influencing the yield $(p<0.05)$. The highest yield (mushroom weight) and $\mathrm{BE}$ value were found on media with ZA (P. flabellatus), NPK (P. ostreatus), TSP (P. sajor-caju and $L$. edodes) (Tables 1, 2, 3, 4). Fertilizers consisted of among others nitrogen element, which presumably enables them to perform better as media cultivation compared to other medium stuffs. Possibly, such was caused by the nitrogen demand for mycelium growth, so the mushroom's fruit body grows fast. Djarwanto et al. (2004) reported that the nitrogen supplementation would increase the yield. It was found that the average yields (mushroom weight) from media with fertilizers were consecutively 178.03 grams (P. flabellatus), 208.93 grams (P. ostreatus), 136.96 grams (P. sajorcaju), and 14.50 grams (L.edodes). Meanwhile, the corresponding BE values are $77.62 \%, 92.09 \%$, $70.05 \%$ and $7.29 \%$, respectively. In the previous research results according to Djarwanto and Suprapti (2001), the BE values were $81.31 \%$ (for P. flabellatus), $74.95 \%$ (P. ostreatus), 86.08\% (P. sajor-caju). Still related, Shah et al. (2004) and Narh et al. (2011) stated that the BE values of mushrooms for P. ostreatus were $62.1-64.7 \%$ and 50.9-59.8\%. Meanwhile, the corresponding BE values were consecutively $24 \%$ for P. sajor-caju (Villaceran, 2006), 50.1-70.6\% for P. flabellatus (Khan et al., 2012), $50.9 \%$ for P. ostreatus and $34.5 \%$ for P. sajor-caju (Obodai et al. (2008). The mushroom yield (i.e. weight and BE values) from $L$. edodes species was very low (Table 4 ), particularly for the mushrooms which were grown on the media with the incorporation of $\mathrm{KCl}, \mathrm{NPK}$, and urea. In this situation, the mushroom primordial (pinhead) failed to develop (dry, wilt and then rotten). Almost all kinds of these media (with KCL, NPK, and urea) seemed unintended for mushroom cultivation, and the watering treatment through mycelium spaces rendered the mushroom rotten. Djarwanto et al. (2001) reported that the $\mathrm{BE}$ value of $L$. edodes was about 3.43-41.01\%. Meanwhile, Diehle and Royse (1991) stated that $\mathrm{BE}$ values $L$. edodes cultivated on nutrientenriched maple and birch sawdust were around $139.8-146.3 \%$.

\section{B. Cultivation of Mushroom on Aren Core}

In the media of aren core's sawn timber for mushroom cultivation, Pleurotus ostreatus, P. flabellatus and P. sajor-caju were also already mature for harvesting on the third day after the growth of their primordial grown; however, for 
Auricularia polytricha, it took about 5-14 days for such harvesting. Based on this research, the fruit body of $A$. polytricha was ready for harvest 5-14 days after its primordial was formed. The mushroom was fully mature when the edge of fruit body thinned out and became wavy, and the mushroom could be easy to pull out. Upadhyay and Sing (2010) reported that the fruit body of Auricularia spp. could be harvested on $3^{\text {rd }}-7^{\text {th }}$ days by examining the pinhead-like appearance. However, Oei (2005), Kristiawan and Budiana (2011) stated that the primordial need 7-10 days for the mushroom's fruit body to become mature.

The initial harvest occasion of $P$. sajorcaju was 136 days after inoculation, similar to that cultivated on the media of several particular wood species as stated by Suprapti and Djarwanto (2001a) i.e. 93-157 days after inoculation. The initial harvest of $A$. polytricha was 99 days that took longer duration than that of previous research which was 74 days after inoculation. Further, those initial harvest occasions which were much later than that of the previous researches conducted far earlier by Suprapti and Djarwanto (1992, 1998, 2001b), were consecutively 54, 62 and 59 days after the mushroom-spawn inoculation.

The yield of mushrooms (i.e. weight and BE values) cultivated on a piece of aren core media is presented in Table 5 . The yield was very low with dwarf (very small) fruit bodies, thereby causing the significant increase in the number of pileus (caps). The harvesting occasion of $P$. ostreatus was the earliest i.e. 43 days after inoculation, whereas the latest was $P$. sajor caju being 136 days after inoculation. Number of the pileus of Auricularia polytricha cultivated on a piece of aren core was 67, much more than that of previous research which numbered only 4.0-15.4 and 5.4-15.5 pileus (Onyango et al., 2011), and 1.0-29.3 and 37.6 pileus (Suprapti \& Djarwanto, 1992, 1998).

L. edodes mushrooms (i.e. originated from Japan and Kalimantan) were not producing fruit body and only showed the mycelial growth which dispersed and thickened on the surface of aren core. Also, on P. cystidiosus mushrooms were only found mycelium and spores that grew on the surface of aren core. Such occurrence was possibly caused by the insufficient food reserves such as potassium, sodium, phosphorous and micro elements. Such elements in amounts were found less in the substrate for the growth of its fruit body.

At the age of four months after mushroomspawn inoculation, most of the sample media had deteriorated, and the mycelial growth was difficult to continue and thickening not occurred due to the separation of fibers bondage on aren core. As a result, the fruit bodies did not grow at all. Some samples of the inoculated cultivation media (aren core) were found rotten that probably was caused by bacterial infection since there was found some bacterial slimy on it.

\section{CONCLUSION}

Two kinds of main stuffs were tested as the cultivation media for edible mushrooms (i.e. aren sawdust and aren stem core's sawn timber). The mushroom species as tested comprised Pleurotus ostreatus, P. flabellatus, P. sajor-caju, P. cystidiosus, Auricularia polytricha (ears mushrooms) and Lentinula edodes (originated from Japan and Kalimantan). It turns out that aren sawdust could be used more favorably for such mushroom-cultivation media. The best growth results of the cultivated mushroom, with respect to the high mushroom yield (i.e. gained fresh weight and biological conversion efficiency/BE values) would be achieved on aren-sawdust media, but added (mixed) with other supplement stuffs that comprised rice bran, $\mathrm{CaCO}_{3}$, gypsum and fertilizers. The proportion of such added stuffs (materials) could vary, such as rice bran $5-20 \%, \mathrm{CaCO}_{3}$ $0.5-2.5 \%$, gypsum $0.5-2.5 \%$ and fertilizers less than $0.5 \%$. On the other hand, the aren core was strongly indicated as less suitable for the cultivation media of such mushroom species. 


\section{ACKNOWLEDGEMENT}

We would like to thank to the Director of the Forest Research and Development Center for facilitating the laboratory and materials for the research.

\section{REFERENCES}

Diehle, D. A., \& Royse, D. J. (1991). Effect of substrate heat treatment on biological efficiency (BE) and size a selected line of Lentinula edodes. In M. J. Maher (Ed.), Proceedings of the $13 \mathrm{TH}$ International Congress on the Science and Cultivation of Edible Fungi/ Dublin/1-6 September 1991. Volume 2. (pp. 517 521). A.A. Balkema/Rotterdam/Brookfield.

Djarwanto, Gandjar, I., \& Suprapti, S. (2002). Growth and productivity of Lentinula edodes from East Kalimantan on 15 types of woods sawdust media (in Bahasa Indonesia). In Proceedings of the MAPEKI National Seminar IV 6-9 August 2001, in Samarinda. (pp. VI-37 - VI43). Samarinda: Faculty of Forestry University of Mulawarman.

Djarwanto, \& Suprapti, S. (2001). Utilization of sawdust of small log diameter for three species oyster mushroom media. In $\mathrm{S}$. Prawirohatmodjo, S. N. Nugroho, \& A. H. Sutjipto (Eds.), Environment Conservation Through Efficiency Utilization of Forest Biomass (pp. 325-347). Debut Press, Jogjakarta.

Djarwanto, \& Suprapti, S. (2010). The effect of seed sources on the growth of oyster mushrooms (in Bahasa Indonesia). Jurnal Penelitian Hasil Hutan, 29(2), 156-168.

Djarwanto, Suprapti, S., Yamto, \& Roliadi, H. (2004). Cultivation of edible mushrooms on sawdust in Karo, North Sumatera. In Procceding of the International Workshop on" Better Utilization of Forest Biomass for Local Community and Environments" 16-17 March, 2004 (pp. 199-210). Bogor-Indonesia: Research and Development Center for Forest Products Technology. Indonesia.

Food and Agriculture Organization. (1982). Growing Jew's ear mushroom (No. RAPA 5.). Food and Agriculture Organization of the United Nations, Bangkok.

Gusmailina, \& Hartoyo. (1989). The chemical analysis of aren stem (Arenga pinnata Merr.) from Jasinga, Bogor. Forest Products Research Journal, 6(6), 353-359.

Heyne, K. (1987). Indonesia useful plants I (In Bahasa Indonesia). Translation. Jakarta: Forestry Research and Development Agency.

Khan, N. A., Ajmal, M., Inam Ul Haq, M., Javed, N., Asif Ali, M., Binyamin, R., \& Khan, S. A. (2012). Impact of sawdust using various woods for effective cultivation of Oyster Mushroom. Pakistan Journal of Botany, 44(1), 399-402.

Kristiawan, B., \& Budiana, E. P. (2011). Using bomass briquette of artificial $\log$ waste as kerosene substitute in sterilization process of Auricularia sp. substrate. In International Conference and Exbibition on Sustainable Energy and Advanced Materials (ICE SEAM 011), SoloIndonesia 3-4, 2011 (pp. 115-122).

Lempang, M. (2012). Aren trees and its production benefits (in Bahasa Indonesia). Info Teknis EBONI, 9, 37-54.

Narh, D. L., Obodai, M., Baka, D., \& Dzomeku, M. (2011). The efficacy of sorghum and millet grains in spawn production and carpophore formation of Pleurotus ostteatus (Jacq. Ex Fr.) Kummer. International Food Research Journal, 18(3), 1143-1148.

Obodai, M., Vowotor, K. A., \& Marfo, K. (2002). Performance of various strains of Pleurotus species under Ghanaian conditions. In Sanchez (Ed.), Mushroom Biology and Mushroom Products (pp. 461-466). Retrieved from http:// wsmbmp.org/proceedings/4th international conference/Documentos Word/B WW Prod/6WW-155 Ghanian Cond.OK.doc.

Oei, P. (2005). Small-scale mushroom cultivation oyster , sbiitake and wood ear mushrooms (pp. 14-17). Wageningen, The Netherlands: Agromisa Foundation and CTA.

Onyango, B. O., Palapala, V. A., Arama, P. F., Waga, S. O., \& Gichimu, B. M. (2011). Suitability of selected supplanted substrates for cultivation of Kenyan native wood ear mushrooms (Auricularia auricula). American Journal of Food Technology, 6(5), 395-403.

Rachman, O., Rohadi, D., \& Balfas, J. (1989). Sawing and machining characteristics of aren wood (Arenga pinnata). Forest Products Research Journal, 6(3), 145-151.

Shah, Z. A., Ashraff, M., \& Ishtiaq, M. (2004). 
Comparative study on cultivation and yield performance of oyster mushroom (Pleurotus ostreatus) on the different substrates (wheat straw, leaves, sawdust). Pakistan Journal of Nutrition, 3(3), 158-160.

Steel, R. G. D., \& Torrie, J. H. (1981). Principles and Procedure of Statistics. New York, USA: McGraw Hill Book Co. Inc.

Suprapti, S. (1988). Cultivation of wood destroying fungi I. The effect of rice bran supplementation on oyster mushroom yield. Forest Products Research Journal, 5(6), 337-339.

Suprapti, S., \& Djarwanto. (1990). Utilization of rubber wood waste for palatable mushroom growing media (in Bahasa Indonesia). In National Scientific Seminar on the Role of Biology in Biological Resource Management Improvement. Yogyakarta: Faculty of Biology Gadjah Mada University.

Suprapti, S., \& Djarwanto. (1992). The efffect of composting jeungjing wood sawdust on the production of palatable mushrooms (in Bahasa Indonesia). In U. Soetisna, B. Tappa, \& E. Sukara (Eds.), Proceedings of the Seminar on Biotechnology Research and Development February, 11-12 1992. (pp. 89-97). Bogor: Reseach Center for Biotechnology, LIPI.

Suprapti, S., \& Djarwanto. (1998). Bioconversion of sawdust of five wood species by black ear-mushroom (Auricularia polytricha). In B. Prasetya, Subyakto, S. Yusuf, B. Subiyanto, Y. Sudiyani, \& E. Hermiati (Eds.), Proceedings of the Second International Wood Science Seminar (pp. E23-E28). R \& D Center for Apllied Physics, LIPI, Indonesia.

Suprapti, S., \& Djarwanto. (2001a). Three kinds of Auricularia mushroom productivites on 20 types of small diameter woods (in Bahasa Indonesia). In Proceedings of the MAPEKI National Seminar IVIV MAPEKI, 6-9 Agustus August 2001, Samarinda. (pp. VI-59 - VI-65). (pp. VI-59 - VI-65). Samarinda: Faculty of Forestry University of Mulawarman
Suprapti, S., \& Djarwanto. (2001b). The utilization of wood $\log$ as a medium of Pleurotus sajorcaju. In S. Prawirohatmodjo, S. N. Nugroho, \& A. H. Sutjipto (Eds.), Environment Conservation Through Efficiency Utilization of Forest Biomass (pp. 333-340). Yogyakarta: Debut Press.

Suprapti, S., \& Djarwanto. (2009). Guidelines for the cultivation of shiitake and oyster mushrooms (in Bahasa Indonesia) (p. 60). Bogor: Forest Products Research and Development Center.

Suprapti, S., Djarwanto, \& Gandjar, I. (1994). The effect of calcium compound supplementation on sawdust substrate to the biological conversion efficiency of mushroom. In The 7 th International congress of Bacteriology and Applied Microbiology Division and Mycology Division, Prague, Crechosslovakia, July 3-8, 1994.

Upadhyay, R. C., \& Sing, M. (2010). Production of edible mushrooms. Industrial Application X. In K. Esser (Ed.), The Mycota (2nd ed., pp. 79-100). Berlin: Springer-Verlag.

Villaceran, A. B., Kalaw, S. P., Natural, P. S., Abella, E. A., \& Reyes, R. G. (2006). Cultivation of Thai and Japanese strains of Pleurotus sajorcaju on rice-straw-based Volvariella volvacea mushromm spent and composted rice straw in central Luzon Region, Philippines. Journal of Agricultural Technology, 2(1), 69-75. 